\title{
Effect of Slag Composition on the Oxidation Kinetics of Alloying Elements during Electroslag Remelting of Stainless Steel: Part-2 Control of Titanium and Aluminum Content
}

\author{
Dong HOU, Zhou-Hua JIANG, ${ }^{*}$ Yan-Wu DONG, Wei GONG, Yu-Long CAO and Hai-bo CAO \\ School of Metallurgy, Northeastern University, Shenyang Liaoning, 110819 China. \\ (Received on March 21, 2017; accepted on April 19, 2017)
}

\begin{abstract}
Kinetics of slag/metal reaction were investigated experimentally using $50 \mathrm{~kg}$ electroslag remelting (ESR) furnace in order to clarify the effect of slag containing different $\mathrm{CaO}$ and $\mathrm{TiO}_{2}$ content on titanium, aluminum and silicon content during the ESR process with $1 \mathrm{Cr} 21 \mathrm{Ni5Ti}$ stainless steel. The results obtained show that the more $\mathrm{CaO}$ content in slag is, the more aluminum content in ingots increases. The $\lg \left([\mathrm{Al}]^{4} /\right.$ $\left[\mathrm{Ti}^{3}\right]^{3}$ ) increases with the increase of slag temperature in the first 13 minutes during the ESR process, and after the slag temperature tends to be stable, the $\lg \left([\mathrm{All}]^{4} /[\mathrm{Ti}]^{3}\right)$ decreases with the increase of $\mathrm{TiO}_{2}$ content in the rest process. The penetration and film theories were employed to analyze the rate determining step of slag/metal reaction, and it was found that the rate determining step of the reaction was the mass transfer of aluminum through the molten steel, silica through the slag and titanium on both of the metal and slag sides. The slag containing low $\mathrm{CaO}$ content combined with extra titania constantly added into molten slag in the first temperature-rising period is suitable for electroslag remelting of $1 \mathrm{Cr} 21 \mathrm{Ni5Ti}$ stainless steel with high titanium and low aluminum content.
\end{abstract}

KEY WORDS: electroslag remelting; kinetics; mass transfer; titanium control; ion and molecule coexistence theory.

\section{Introduction}

During the electroslag remelting (ESR) with steel containing active alloying elements, the macrosegregation of aluminum, titanium and silicon content along the axial direction of ingot has not been resolved well till today. ${ }^{1,2)}$ Not only the reactions among $\mathrm{Al}+\mathrm{Al}_{2} \mathrm{O}_{3}, \mathrm{Si}+\mathrm{SiO}_{2}$ and $\mathrm{Ti}+\mathrm{TiO}_{2}$ systems but also the oxidation reactions caused by ferrous oxide, influence the alloying element content, which makes the active alloying element control difficultly. Therefore, it is particularly urgent to provide reliable active alloying element in ingot control technology based on thermodynamic and kinetic analysis during the ESR process.

Until today, research on the macrosegregation of aluminum, titanium and silicon in stainless steel with high titanium and low aluminum content during the ESR process is still continuing, and thermodynamic study of the subject $^{3-9)}$ and reports on the modeling of the chemical reactions occurring during ESR process ${ }^{10,11)}$ have been published. Hou ${ }^{3,4)}$ studied the effect of slag on titanium, silicon and aluminum content in superalloy based on slag-metal interaction experiment in a resistant furnace, and illustrated that the $\mathrm{CaO}$ has large effect on the activities of $\mathrm{Al}_{2} \mathrm{O}_{3}$, $\mathrm{TiO}_{2}$ and $\mathrm{SiO}_{2}$ based on thermodynamics. Cheng ${ }^{6}$ investigated the relationship between titanium and aluminum

\footnotetext{
* Corresponding author: E-mail: jiangzh@smm.neu.edu.cn DOI: http://dx.doi.org/10.2355/isijinternational.ISIJINT-2017-148
}

based on the experiments and thermodynamic equilibrium, by which the $\mathrm{TiO}_{2}$ content was measured in order to make the titanium uniform from top to bottom in ingot during the electroslag remelting process. Nonetheless, these study focused on the slag designing by thermodynamic equilibrium at a fixed temperature, and do not reveal the effect of slag on the change of alloying element along the height of ingot. Schwerdtfeger ${ }^{10)}$ investigated the mechanism of mass transfer occurring in electroslag remelting process, and illustrated the details of processes controlling solute redistribution during the remelting of stainless steel quantitatively. However, the model neglected the change of temperature at the beginning of ESR process, and did not provide an effective way to improve the homogeneity of composition.

As the ESR is a mass transfer process among multiphase reaction system under dynamic conditions of temperature, slag composition and oxygen increment in slag, study of the effect of the each component in the slag consisting of $\mathrm{CaO}-\mathrm{CaF}_{2}-\mathrm{Al}_{2} \mathrm{O}_{3}-\mathrm{SiO}_{2}-\mathrm{TiO}_{2}-\mathrm{MgO}-\mathrm{FeO}$ on the concentrations of the alloying elements involved in ingot has been insufficient till now. Because of this, kinetics of slag/metal reaction were investigated experimentally using $50 \mathrm{~kg}$ electroslag remelting furnace to clarify the effect of $\mathrm{CaO}$ and $\mathrm{TiO}_{2}$ content on the concentrations of the aluminum, titanium and silicon in $1 \mathrm{Cr} 21 \mathrm{Ni} 5 \mathrm{Ti}$ stainless steel ingot. The present research is expected to provide active alloying elements control technology during the ESR of steel/alloy with high titanium and low aluminum content. Based on the 
mass transfer model established in Part $1,{ }^{11)}$ the experiments were carried out by controlling the slag composition and remelting process to improve the macrosegregation of alloying elements from the bottom to top of ingot in this Part 2.

\section{Experimental}

Three experimental heats were carried out using a 50-kg scale ESR furnace under argon atmosphere. The consumable electrode material used in each heat was produced by a vacuum induction furnace and its chemical composition is listed in Table 1. The oxide layer of electrode with a shape of $60 \mathrm{~mm}$ in diameter and $2000 \mathrm{~mm}$ in length was eliminated mechanically before electroslag remelting. The electroslag remelting equipment is shown in Fig. 1. The inner diameter of water cooled copper mold is $134 \mathrm{~mm}$.

According to the previous study, ${ }^{3)}$ laboratory experiments were carried out with three kinds of mixtures. The slag in each heat was roasted at $873 \mathrm{~K}\left(600^{\circ} \mathrm{C}\right)$ in a dry box for at least 4 hours to remove the moisture in the slag before ESR experiment. About $3.2 \mathrm{~kg}$ of slag mixtures was used in each experiment by solid slag starting technique. In each heat, the input current, voltage, and outlet temperature of the mold cooling water were kept at about $3000 \mathrm{~A}, 38 \mathrm{~V}$, and $298 \mathrm{~K}$ $\left(25^{\circ} \mathrm{C}\right)$ during ESR process, respectively. The remelting rate is approximately $66 \mathrm{~kg} \cdot \mathrm{h}^{-1}$ during the process. In experimental A (with slag S1), B (with slag S2) and C (with slag S3), high purity argon gas was introduced into ESR equip-

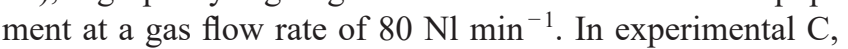
the extra $200 \mathrm{~g} \mathrm{TiO}_{2}$ was continuously added into molten slag in the first 13 minutes, and $20 \mathrm{~g}$ deoxidizer aluminum was added into molten slag during the ESR process.

In order to investigate the effect of slag on the chemi-

Table 1. Chemical composition of the $1 \mathrm{Cr} 21 \mathrm{Ni} 5 \mathrm{Ti}(\mathrm{wt} \%)$.

\begin{tabular}{ccccccc}
\hline $\mathrm{C}$ & $\mathrm{Si}$ & $\mathrm{Mn}$ & $\mathrm{Cr}$ & $\mathrm{Ni}$ & $\mathrm{Al}$ & $\mathrm{Ti}$ \\
\hline 0.11 & 0.66 & 0.58 & 20.72 & 5.22 & 0.03 & 0.66 \\
\hline
\end{tabular}

Table 2. Chemical composition of ESR slag (wt \%).

\begin{tabular}{cccccccc}
\hline Slag & $\mathrm{CaF}_{2}$ & $\mathrm{CaO}$ & $\mathrm{Al}_{2} \mathrm{O}_{3}$ & $\mathrm{TiO}_{2}$ & $\mathrm{SiO}_{2}$ & $\mathrm{MgO}$ & $\lg \left(X_{\mathrm{TiO}_{2}}^{3} / X_{\mathrm{Al}_{2} \mathrm{O}_{3}}^{2}\right)$ \\
\hline $\mathrm{S} 1$ & 63.05 & 4.80 & 17.81 & 4.41 & 1.07 & 8.86 & -2.33 \\
$\mathrm{~S} 2$ & 54.87 & 16.83 & 17.56 & 4.36 & 1.26 & 5.12 & -2.38 \\
$\mathrm{~S} 3$ & 55.25 & 4.92 & 19.91 & 8.93 & 1.32 & 9.67 & -1.57 \\
\hline
\end{tabular}
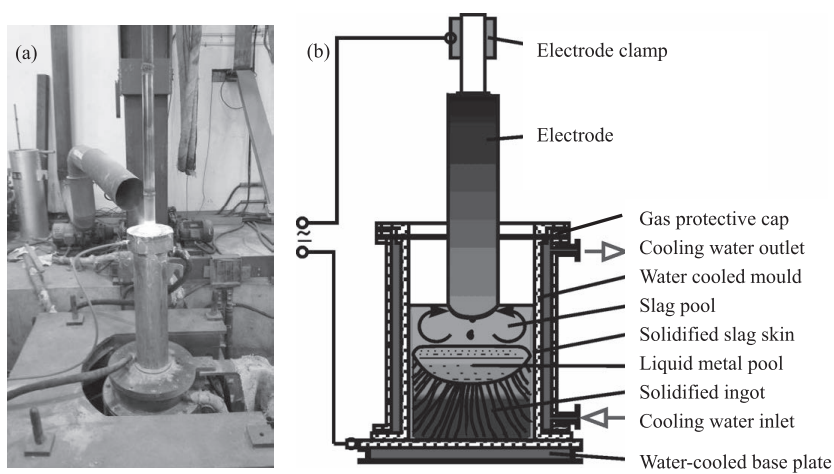

Fig. 1. Electroslag remelting equipment: (a) Equipment image, and (b) Schematic diagram. cal composition of ingots during the ESR, the silicon and titanium contents from bottom to the top of the ingots in each experiment were analyzed by direct reading spectrometry, the content of soluble aluminum from bottom to the top of the ingots was determined by the inductively coupled plasma-mass spectroscopy (ICP-MS). Slag samples were taken from the molten slag in the water cooled copper mold using the quartz tube at corresponding height in remelted ingot. The chemical compositions of slag samples at $5 \mathrm{~cm}$ height of remelted ingot in each experiment are listed in Table 2.

\section{Results and Discussion}

\subsection{Reassessment of the $\gamma$ Values of $\mathrm{TiO}_{2}$ and $\mathrm{Al}_{2} \mathrm{O}_{3}$}

It is important to have exact knowledge about the $\gamma$ values of $\mathrm{TiO}_{2}$ and $\mathrm{Al}_{2} \mathrm{O}_{3}$ in ESR slag to control Ti and $\mathrm{Al}$ contents in ESR ingots. As stated in the Part $1,{ }^{11)}$ the $\gamma$ values of $\mathrm{TiO}_{2}$ and $\mathrm{Al}_{2} \mathrm{O}_{3}$ have to be reassessed appropriately.

\subsubsection{Thermodynamic Analysis of the Experimental Results}

Equations (1) and (2) $)^{8)}$ are employed to investigate the experimental results in order to better understand the effect of slag and remelting process on the change of aluminum, titanium and silicon element concentration in ingot.

$$
\begin{aligned}
& 3[\mathrm{Ti}]+2\left(\mathrm{Al}_{2} \mathrm{O}_{3}\right)=4[\mathrm{Al}]+3\left(\mathrm{TiO}_{2}\right) \\
& \lg K(\mathrm{Ti}, \mathrm{Al})=\lg \frac{a_{\mathrm{Al}}^{4} \cdot a_{\mathrm{TiO}_{2}}^{3}}{a_{\mathrm{Ti}}^{3} \cdot a_{\mathrm{Al}_{2} \mathrm{O}_{3}}^{2}}=\lg \frac{f_{\mathrm{Al}}^{4} \cdot[\mathrm{Al}]^{4}}{f_{\mathrm{Ti}}^{3} \cdot[\mathrm{Ti}]^{3}} \\
& +\lg \frac{\gamma_{\mathrm{TiO}_{2}}^{3} \cdot X_{\mathrm{TiO}_{2}}^{3}}{\gamma_{\mathrm{Al}_{2} \mathrm{O}_{3}}^{2} \cdot X_{\mathrm{Al}_{2} \mathrm{O}_{3}}^{2}}=-\frac{35300}{T}+9.94 \\
& X_{i}=\frac{w_{i} / \mathbf{M}_{i}}{\sum w_{i} / \mathbf{M}_{i}} \\
& \lg f_{i}=\sum\left(e_{i}^{j} w[\% j]+r_{i}^{j} w[\% j]^{2}\right)
\end{aligned}
$$

Where $\gamma_{\mathrm{TiO}_{2}}$ and $\gamma_{\mathrm{Al}_{2} \mathrm{O}_{3}}$ are the activities of $\mathrm{TiO}_{2}$ and $\mathrm{Al}_{2} \mathrm{O}_{3}$ in slag; $X_{\mathrm{TiO}_{2}}$ and $X_{\mathrm{Al}_{2} \mathrm{O}_{3}}$ are the molar fraction of $\mathrm{TiO}_{2}$ and $\mathrm{Al}_{2} \mathrm{O}_{3}$ in slag, which can be calculated by the Eq. (3) and the $\mathrm{M}_{i}$ is the molar mass; $f_{\mathrm{Al}}$ and $f_{\mathrm{Ti}}$ are the activity coefficients of aluminum and titanium, which can be calculated in Part 1. ${ }^{11)}$

Thus, the $\lg \left(X_{\mathrm{TiO}_{2}}^{3} / X_{\mathrm{Al}_{2} \mathrm{O}_{3}}^{2}\right)$ of each slag can be calculated by Eq. (3) and results are listed in Table 2. The $\lg \left(X_{\mathrm{TiO}_{2}}^{3} / X_{\mathrm{Al}_{2} \mathrm{O}_{3}}^{2}\right)$ of slag $\mathrm{S} 1$ being close to slag $\mathrm{S} 2$ means that the $\lg \left([\mathrm{Al}]^{4} /[\mathrm{Ti}]^{3}\right)$ of the ingot remelting with slag S1 should be the same as that of S2 according to the Eq. (2). However, the ingot remelting with S2 has the larger $\lg \left([\mathrm{Al}]^{4} /[\mathrm{Ti}]^{3}\right)$ than that of $\mathrm{S} 1$, which does not match with the conclusion above, as shown in Fig. 2. Compared with the components in slag $\mathrm{S} 1$ and $\mathrm{S} 2$, the component $\mathrm{CaO}$ may play an important role in controlling the activity coefficients of $\mathrm{TiO}_{2}$ and $\mathrm{Al}_{2} \mathrm{O}_{3}\left(\gamma_{\mathrm{TiO}_{2}}\right.$ and $\left.\gamma_{\mathrm{Al}_{2} \mathrm{O}_{3}}\right)$ in slag according to the Eq. (2), which has been confirmed in the previous work. ${ }^{3)}$ It also can be concluded that when there is fixed aluminum content in ingots, $\mathrm{S} 2$ needs more $\mathrm{TiO}_{2}$ content in slag to prevent titanium loss caused by the reaction of titanium with alumina, and its disadvantage has been studied in the 
previous work. $^{3)}$

As shown in Fig. 2, both the slag S1 and S2 having the rising trend of $\lg \left([\mathrm{Al}]^{4} /[\mathrm{Ti}]^{3}\right)$ in the first $13 \mathrm{~cm}$ height of remelted ingot means that the temperature of slag is continuously elevated (assuming from $1750 \mathrm{~K}$ to $1950 \mathrm{~K}$ according to Part $1^{11)}$ ) at the beginning of the ESR process, which makes the $\lg K(\mathrm{Ti}, \mathrm{Al})$ tend to increase according to the Eq. (2). After the temperature reaches $1950 \mathrm{~K}$ (over $13 \mathrm{~cm}$ height of remelted ingot), both the slag $\mathrm{S} 1$ and $\mathrm{S} 2$ have the decreasing trend of $\lg \left([\mathrm{Al}]^{4} /[\mathrm{Ti}]^{3}\right)$ in the rest ingot because of the increase of $\mathrm{TiO}_{2}$ that makes the $\lg \left(X_{\mathrm{TiO}_{2}}^{3} / X_{\mathrm{Al}_{2} \mathrm{O}_{3}}^{2}\right)$ tend to increase according to the Eq. (2).

Based on the analysis above, more $\mathrm{TiO}_{2}$ should be added into slag $\mathrm{S} 1$ to prevent titanium loss caused by the reaction of titanium with alumina, such as slag S3. In addition, as the $\lg K(\mathrm{Ti}, \mathrm{Al})$ in Eq. (2) increases with the increase of slag temperature in the first 13 minutes during the ESR process, the extra $\mathrm{TiO}_{2}$ should be continuously added into the molten

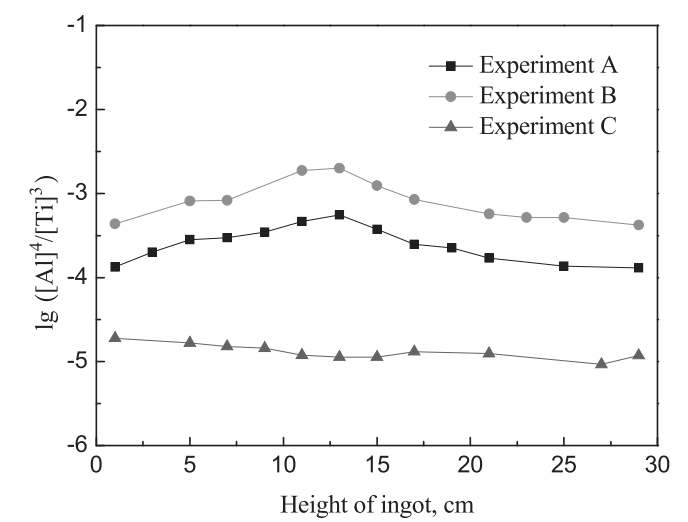

Fig. 2. Change of $\lg \left([\mathrm{Al}]^{4} /[\mathrm{Ti}]^{3}\right)$ with height of ingot in each heat.

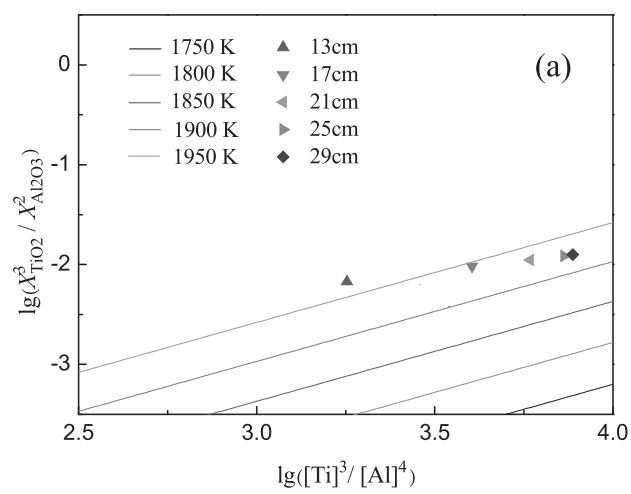

slag (the value is the difference between the $\mathrm{TiO}_{2}$ content in slag calculated at $1950 \mathrm{~K}$ and $1750 \mathrm{~K}$ ) in the first 13 minutes during the ESR process, to promote the thermodynamics equilibrium between the $\mathrm{Al}+\mathrm{Al}_{2} \mathrm{O}_{3}$ and $\mathrm{Ti}+\mathrm{TiO}_{2}$ system, which was carried out in experimental $\mathrm{C}$.

\subsubsection{Effect of Titania on Activity Coefficients of Titania and Alumina in Slag}

Based on the Eqs. (40)-(47) in Part 1, ${ }^{11)}$ the $\gamma_{\mathrm{TiO}_{2}}$ and $\gamma_{\mathrm{Al}_{2} \mathrm{O}_{3}}$ of slag S1 and S2 listed in Table 2 can be calculated by ion and molecule coexistence theory of slag, and then the change of $\lg \left(X_{\mathrm{TiO}_{2}}^{3} / X_{\mathrm{Al}_{2} \mathrm{O}_{3}}^{2}\right)$ with $\lg \left([\mathrm{Ti}]^{3} /[\mathrm{Al}]^{4}\right)$ can be obtained based on the Eq. (2), as shown in Figs. 3(a) (Experimental A) and 3(b) (Experimental B) with each experimental points at 13, 17, 21, 25, $29 \mathrm{~cm}$ height of ingot. It is considered that the experimental points at $13,17,21$, $25,29 \mathrm{~cm}$ height of each ingot should be increased along the calculated lines at $1950 \mathrm{~K}\left(1677^{\circ} \mathrm{C}\right)$ because the temperature has been stable during the rest ESR process. However, as the height of the ingot increases, the slope of experimental points at 13-29 cm height in each experiment is less than the calculated line at $1950 \mathrm{~K}\left(1677^{\circ} \mathrm{C}\right)$, the slope of which is one according to the Eq. (2). There must be another factor that influences the value of $\lg \left(\gamma_{\mathrm{Al}_{2} \mathrm{O}_{3}}^{2} / \gamma_{\mathrm{TiO}_{2}}^{3}\right)$. It may be the increase of $\mathrm{TiO}_{2}$ content at the $13-29 \mathrm{~cm}$ of ingots that decrease the value of $\lg \left(\gamma_{\mathrm{Al}_{2} \mathrm{O}_{3}}^{2} / \gamma_{\mathrm{TiO}_{2}}^{3}\right)$.

Based on the Eqs. (40)-(47) in Part 1, ${ }^{11)}$ the influence of $\mathrm{TiO}_{2}$ content on activity coefficients of $\mathrm{Al}_{2} \mathrm{O}_{3}, \mathrm{TiO}_{2}$ and $\mathrm{FeO}$ were calculated by using the slag (the ratio of each component is, $\mathrm{CaF}_{2}$ : $\mathrm{CaO}: \mathrm{Al}_{2} \mathrm{O}_{3}: \mathrm{MgO}: \mathrm{SiO}_{2}$ : $\mathrm{FeO}$ : $\left.\mathrm{TiO}_{2}=62: 5: 20: 10: 1: 0.1: X\right)$ at the temperature of 1850 $\mathrm{K}$ and $1950 \mathrm{~K}\left(1577^{\circ} \mathrm{C}\right.$ and $\left.1677^{\circ} \mathrm{C}\right)$, as shown in Fig. 4(a). Then the change of $\lg \left(\gamma_{\mathrm{Al}_{2} \mathrm{O}_{3}}^{2} / \gamma_{\mathrm{TiO}_{2}}^{3}\right), \lg \left(\gamma_{\mathrm{TiO}_{2}} / \gamma_{\mathrm{FeO}}^{2}\right)$

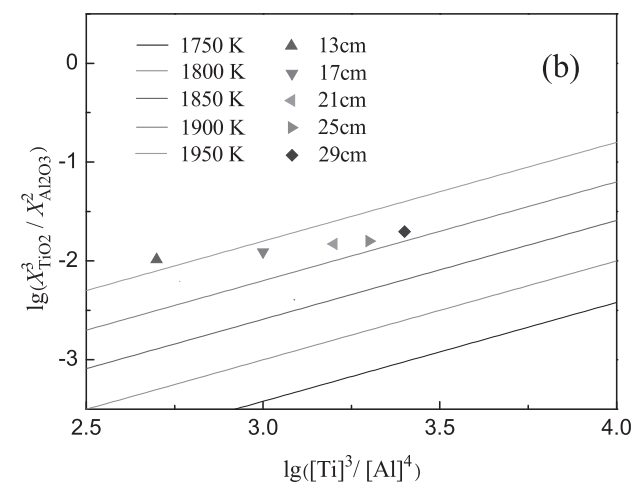

Fig. 3. Change of the $\lg \left(X_{\mathrm{TiO}_{2}}^{3} / X_{\mathrm{Al}_{2} \mathrm{O}_{3}}^{2}\right)$ with $\lg \left([\mathrm{Ti}]^{3} /[\mathrm{Al}]^{4}\right)$.
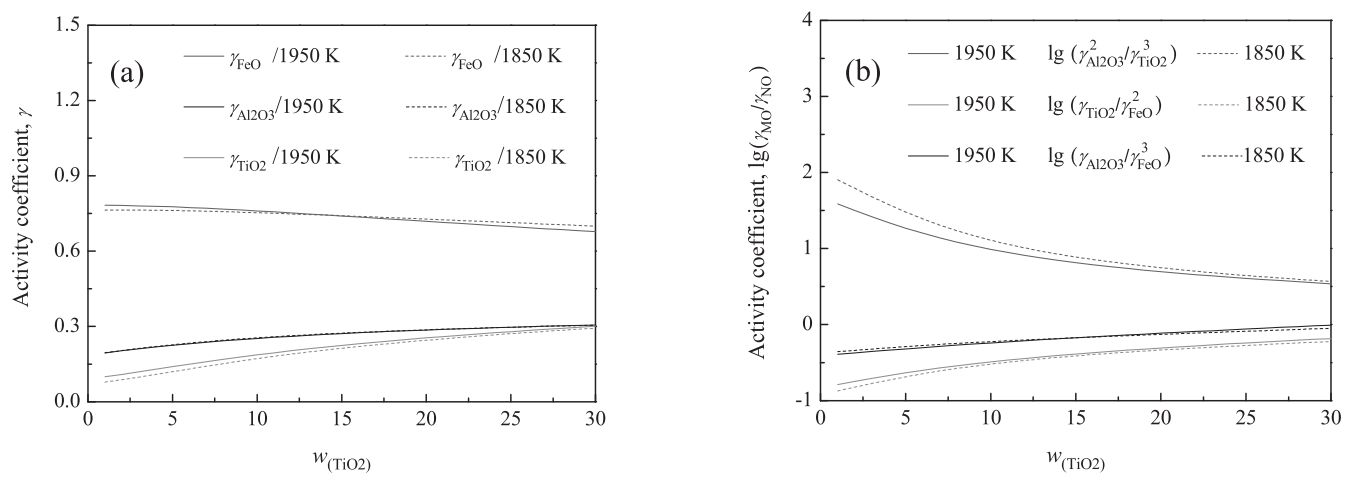

Fig. 4. Change of the activity coefficients with $\mathrm{TiO}_{2}$ content in slag. 
and $\lg \left(\gamma_{\mathrm{Al}_{2} \mathrm{O}_{3}} / \gamma_{\mathrm{FeO}}^{3}\right)$ with the increase of $\mathrm{TiO}_{2}$ can also be acquired, as shown in Fig. 4(b). It is clear that the value of $\lg \left(\gamma_{\mathrm{Al}_{2} \mathrm{O}_{3}}^{2} / \gamma_{\mathrm{TiO}_{2}}^{3}\right)$ decreases with the increase of $\mathrm{TiO}_{2}$ content, which makes the slope of experimental points at 13-29 cm height of ingot being less than one, as shown in Fig. 3.

In order to determine the addition of $\mathrm{TiO}_{2}$ into slag during the ESR process, three experimental heats of interaction between slag and metal in a $\mathrm{MoSi}_{2}$ resistance furnace were carried out with $500 \mathrm{~g} 1 \mathrm{Cr} 21 \mathrm{Ni} 5 \mathrm{Ti}$ stainless steel and $120 \mathrm{~g}$ slag mixtures at the temperature of $1850 \mathrm{~K}\left(1577^{\circ} \mathrm{C}\right)$, and the slag composition is listed in Table 3. In each heat, the aluminum particles were added into slag mixtures before the experiment, and the addition of aluminum particles is listed in Table 3. The details of the experimental process can be seen in the previous study. ${ }^{3)}$

Steel samples No.1 through No.4 were taken from the molten steel after a prescribed amount of slag listed in Table 3 was put onto the surface of the molten metal for 15, 25, 35 and 45 minutes, respectively. Slag sample was taken from the molten slag after the slag had melted for 45 minute. Then the contents of titanium and soluble aluminum in each steel sample were determined, and the results of steel samples were shown in Fig. 5. It is clear that the reaction between slag and metal nearly reaches the thermodynamic equilibrium at 45 minute. Thus, the contents of $\mathrm{TiO}_{2}$ and $\mathrm{Al}_{2} \mathrm{O}_{3}$ in slag, and the $\mathrm{Al}$, Ti in steel samples at 45 minute in each experiment were used to determine the $\mathrm{TiO}_{2}$ content in Fig. 6.

Based on the Eqs. (40)-(47) in Part $1^{11)}$ and Eq. (2), the $\mathrm{TiO}_{2}$ content in slag (the ratio of each component is, $\mathrm{CaF}_{2}$ : $\left.\mathrm{CaO}: \mathrm{Al}_{2} \mathrm{O}_{3}: \mathrm{SiO}_{2}: \mathrm{MgO}: \mathrm{TiO}_{2}=62: 5: 20: 1: 10: X\right)$ used for remelting of stainless steel with different titanium and aluminum contents can be calculated, and the change of $\lg \left(X_{\mathrm{TiO}_{2}}^{3} / X_{\mathrm{Al}_{2} \mathrm{O}_{3}}^{2}\right)$ with $\lg \left([\mathrm{Ti}]^{3} /[\mathrm{Al}]^{4}\right)$ is shown in Fig. 6. It is clear that the experimental points (T1, T2 and T3) are in line with the calculated results. The slope of each solid line should be one according to the Eq. (2), however, the influence of $\mathrm{TiO}_{2}$ content on value of $\lg \left(\gamma_{\mathrm{Al}_{2} \mathrm{O}_{3}}^{2} / \gamma_{\mathrm{TiO}_{2}}^{3}\right)$ makes the slope of each solid line less than one (the slope of dashed line is one), as shown in Fig. 6.

Above all, the $\mathrm{TiO}_{2}$ content in initial slag during the ESR experimental $\mathrm{C}$ can be determined, and the extra addition of $\mathrm{TiO}_{2}$ in the first 13 minutes can also be acquired. Thus, in experimental $\mathrm{C}$, the concentration of aluminum and titanium along the axial direction of ingot was uniform, and the change of $\lg \left([\mathrm{Al}]^{4} /[\mathrm{Ti}]^{3}\right)$ with height in ingot is close to the straight line, as shown in Fig. 2. It also can be concluded that the reaction $3[\mathrm{Ti}]+2\left(\mathrm{Al}_{2} \mathrm{O}_{3}\right)=4[\mathrm{Al}]+3\left(\mathrm{TiO}_{2}\right)$ at the interface of metal pool/slag in Exp.C is nearly close to the thermodynamic equilibrium. As shown in Fig. 6, the experimental points at 13,21, $29 \mathrm{~cm}$ height of Exp.C ingot located at the line of $1950 \mathrm{~K}\left(1677^{\circ} \mathrm{C}\right)$ provide the best

Table 3. Chemical composition of slag in resistance furnace experiment (wt\%).

\begin{tabular}{cccccccc}
\hline Slag & $\mathrm{CaF}_{2}$ & $\mathrm{CaO}$ & $\mathrm{SiO}_{2}$ & $\mathrm{Al}_{2} \mathrm{O}_{3}$ & $\mathrm{TiO}_{2}$ & $\mathrm{MgO}$ & Al added \\
\hline $\mathrm{T} 1$ & 62.5 & 5 & 0.5 & 20 & 2 & 10 & $0.5 \mathrm{~g}$ \\
$\mathrm{~T} 2$ & 59.5 & 5 & 0.5 & 20 & 5 & 10 & $0.2 \mathrm{~g}$ \\
$\mathrm{~T} 3$ & 54.5 & 5 & 0.5 & 20 & 10 & 10 & $1.3 \mathrm{~g}$ \\
\hline
\end{tabular}
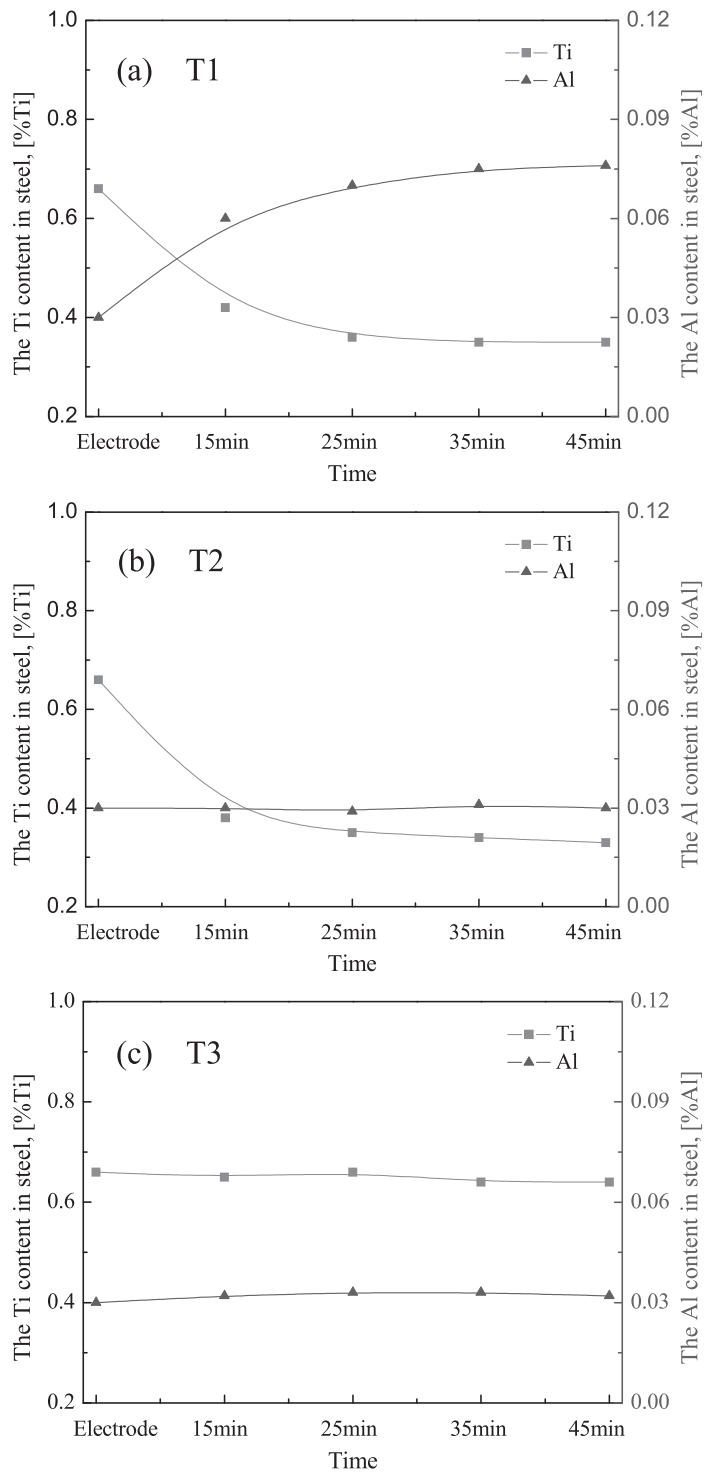

Fig. 5. Change of aluminum and titanium content in steel with time after each slag addition.

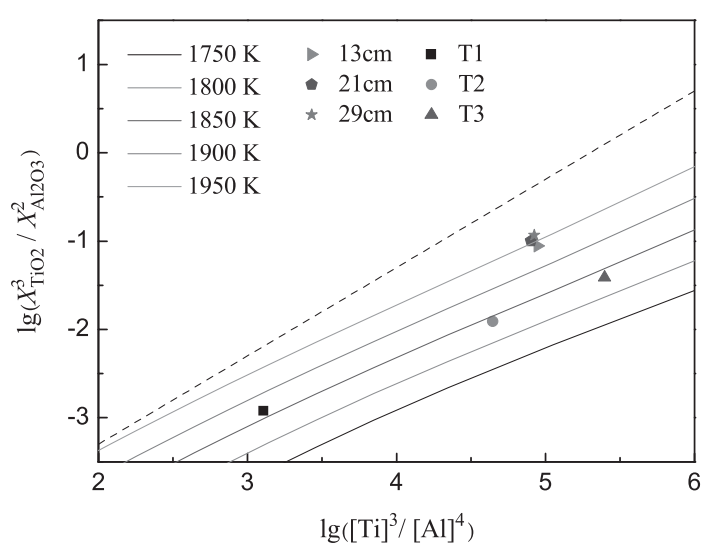

Fig. 6. Change of the $\lg \left(X_{\mathrm{TiO}_{2}}^{3} / X_{\mathrm{Al}_{2} \mathrm{O}_{3}}^{2}\right)$ with $\lg \left([\mathrm{Ti}]^{3} /[\mathrm{Al}]^{4}\right)$.

proof that the temperature of the reactions at the interface of metal pool/slag is $1950 \mathrm{~K}\left(1677^{\circ} \mathrm{C}\right)$, which was estimated in Part 1. ${ }^{11)}$

\subsection{Concentration Change of $\mathrm{Al}, \mathrm{Ti}$ and $\mathrm{Si}$ \\ 3.2.1. Experimental A and B}

From the results described above, it was understood that 
the concentrations of the elements vary from the bottom to the top of the ingot are influenced by the slag composition and remelting process, and this process is also an exchange reaction among $\mathrm{Al}+\mathrm{Al}_{2} \mathrm{O}_{3}, \mathrm{Si}+\mathrm{SiO}_{2}, \mathrm{Ti}+\mathrm{TiO}_{2}$ and $\mathrm{Fe}+\mathrm{FeO}$ systems. Thus, the mass transfer model in Part $1^{11)}$ is employed to investigate the details of the processes controlling solute redistribution in the molten metal, and estimate the rate-determining step in these respective element processes.

Experience has shown that during the ESR process iron oxide is continuously added into the slag due to the consumable electrode oxidation with air and oxygen transfer in the air/slag/metal. ${ }^{12)}$ If assuming the remelting rate during the whole ESR process is $66 \mathrm{~kg} / \mathrm{h}$, the area of the electrode tip and volume/reaction time $V_{\mathrm{m}} / t_{\mathrm{e}}$ can be taken as $36.91 \mathrm{~cm}^{2}$ and $2.55 \mathrm{~cm}^{3} / \mathrm{s}$, respectively, according to Eqs. (52) and (53) in the Part 1. ${ }^{11)}$ The increment of iron oxide $\left(I_{\mathrm{FeO}}\right)$ during the ESR process can be expressed by the following Eq. (5), and the change of ferrous oxide increment with time can be acquired, as shown in Fig. 7.

$$
\begin{aligned}
I_{\mathrm{FeO}}= & W_{\mathrm{m}} \cdot \mathrm{M}_{\mathrm{FeO}} \\
& \left(\frac{2 \times[\% \mathrm{Si}]_{\mathrm{Ele} .}}{\mathrm{M}_{\mathrm{Si}}}+\frac{2 \times[\% \mathrm{Ti}]_{\mathrm{Ele}}}{\mathrm{M}_{\mathrm{Ti}}}+\frac{1.5 \times[\% \mathrm{Al}]_{\mathrm{Ele}}}{\mathrm{M}_{\mathrm{Al}}}\right. \\
& \left.-\frac{2 \times[\% \mathrm{Si}]_{\text {Ingot }}}{\mathrm{M}_{\mathrm{Si}}}-\frac{2 \times[\% \mathrm{Ti}]_{\text {Ingot }}}{\mathrm{M}_{\mathrm{Ti}}}-\frac{1.5 \times[\% \mathrm{Al}]_{\text {Ingot }}}{\mathrm{M}_{\mathrm{Al}}}\right)
\end{aligned}
$$

Where: $W_{\mathrm{m}}$ is the mass remelting rate; $\mathrm{M}_{\mathrm{i}}$ is the molar mass of $i$ element.

As can be seen in Figs. 7(a) (Experimental A) and 7(b) (Experimental B), the increment of iron oxide $\left(I_{\mathrm{FeO}}\right)$ in the first 780 seconds $(13 \mathrm{~cm}$ height of the ingot) during the ESR process can be expressed by ellipse Eq. (6) in order to obtain the smooth curve. After the 780 second, the tangent line of ellipse is employed to illustrate the stable increment of iron oxide.

$$
\frac{\left(T_{\text {time }}-780\right)^{2}}{780^{2}}+\frac{\left(0.28-I_{\mathrm{FeO}}\right)^{2}}{0.25^{2}}=1
$$

Where: $T_{\text {time }}$ is the remelting time in the ESR process, $\mathrm{s}$. Same as the iron oxide, the increment of slag temperature ( $\left.T_{\text {Slag }}\right)$ at the interface of droplet metal/slag and pool metal/ slag in the first 780 seconds ( $13 \mathrm{~cm}$ height of the ingot) can be expressed by ellipse Eq. (7) to obtain the smooth curve. If assuming that the approximate average depth of the cylinder $h_{\mathrm{r}}$ in metal pool is $15 \mathrm{~mm}$, the depth of the arc $h_{\mathrm{e}}$ is

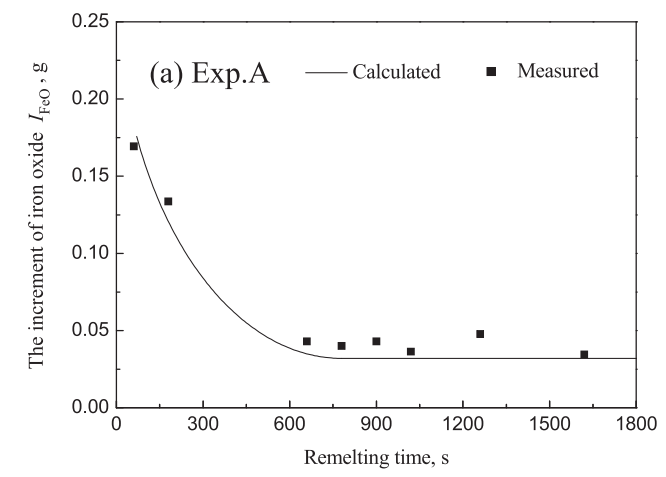

$40 \mathrm{~mm}$, and the radius of crystallizer $R_{\mathrm{C}}$ is $67 \mathrm{~mm}$, the area and volume of the molten metal pool can be calculated as $141.03 \mathrm{~cm}^{2}$ and $399.57 \mathrm{~cm}^{3}$, respectively. Thus, the change of the molten metal pool volume $\left(V_{\text {Pool }}\right)$ with time can be determined by ellipse Eq. (8), as shown in Fig. 8.

$$
\begin{gathered}
\frac{\left(T_{\text {time }}-780\right)^{2}}{780^{2}}+\frac{\left(1950-T_{\text {Slag }}\right)^{2}}{200^{2}}=1 \\
\frac{\left(T_{\text {time }}-780\right)^{2}}{780^{2}}+\frac{\left(V_{\text {Pool }}\right)^{2}}{396^{2}}=1 \ldots . .
\end{gathered}
$$

Based on the analysis above, the mass-transfer model of oxidation of alloying elements during ESR of stainless steel has been established. Figures 9-11 show the observed results of the change of the $\mathrm{Ti}, \mathrm{Al}$ and $\mathrm{Si}$ content with height of the ingots in experimental A and B, in comparison with the results calculated based on the model described above. In Figs. 9-11 the experimentally determined concentration curves are shown together with the calculated results.

As shown in Fig. 9(a), in experimental A the oxidation of titanium has occurred to a less extent compared to that in the experimental B (Fig. 9(b)). While in experimental A the increase of aluminum content (Fig. 10(a)) is less than that in experiment B (Fig. 10(b)). Compared slag S1 with $\mathrm{S} 2$, even the $\lg \left(X_{\mathrm{TiO}_{2}}^{3} / X_{\mathrm{Al}_{2} \mathrm{O}_{3}}^{2}\right)$ of slag $\mathrm{S} 1$ is close to that of slag $\mathrm{S} 2$, the different $\mathrm{CaO}$ content changing the activity coefficients of $\mathrm{TiO}_{2}$ and $\mathrm{Al}_{2} \mathrm{O}_{3}$ makes the ingots have the different chemical composition of aluminum and titanium content, which has been reported in the previous study. 3 )

As can be seen in Figs. 10(a) and 10(b), both in experimental $\mathrm{A}$ and $\mathrm{B}$ the aluminum content in ingot have the rising trend in the first $13 \mathrm{~cm}$ height of ingot, while after

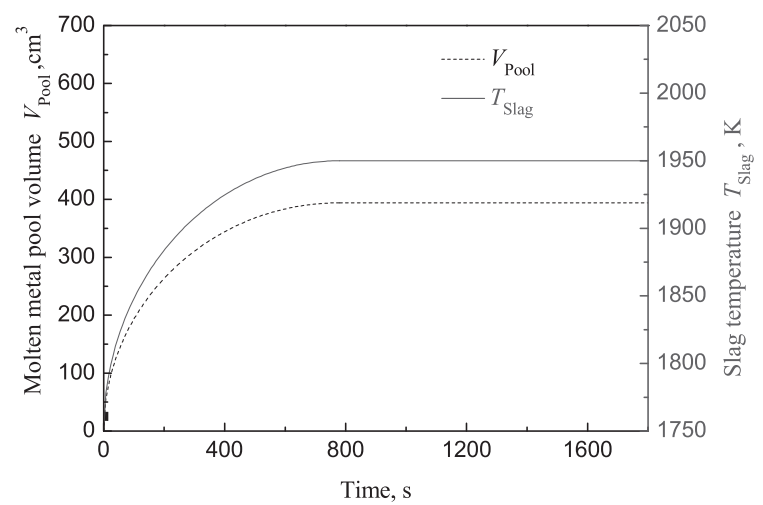

Fig. 8. Change of metal pool volume and temperature with time during the ESR process.

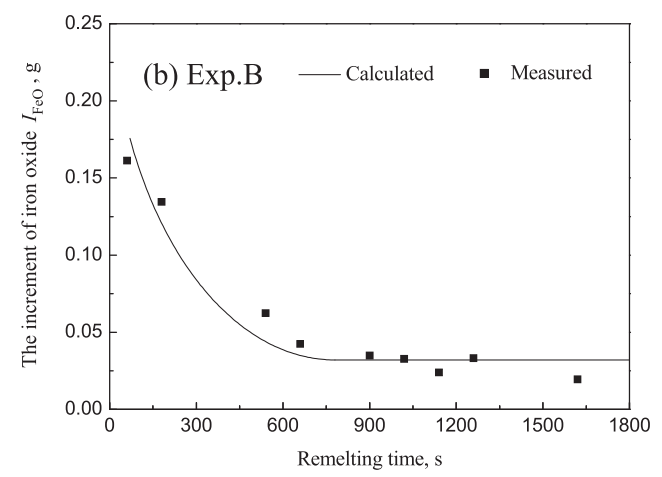

Fig. 7. Change of ferrous oxide mass increment with time during the ESR process. 

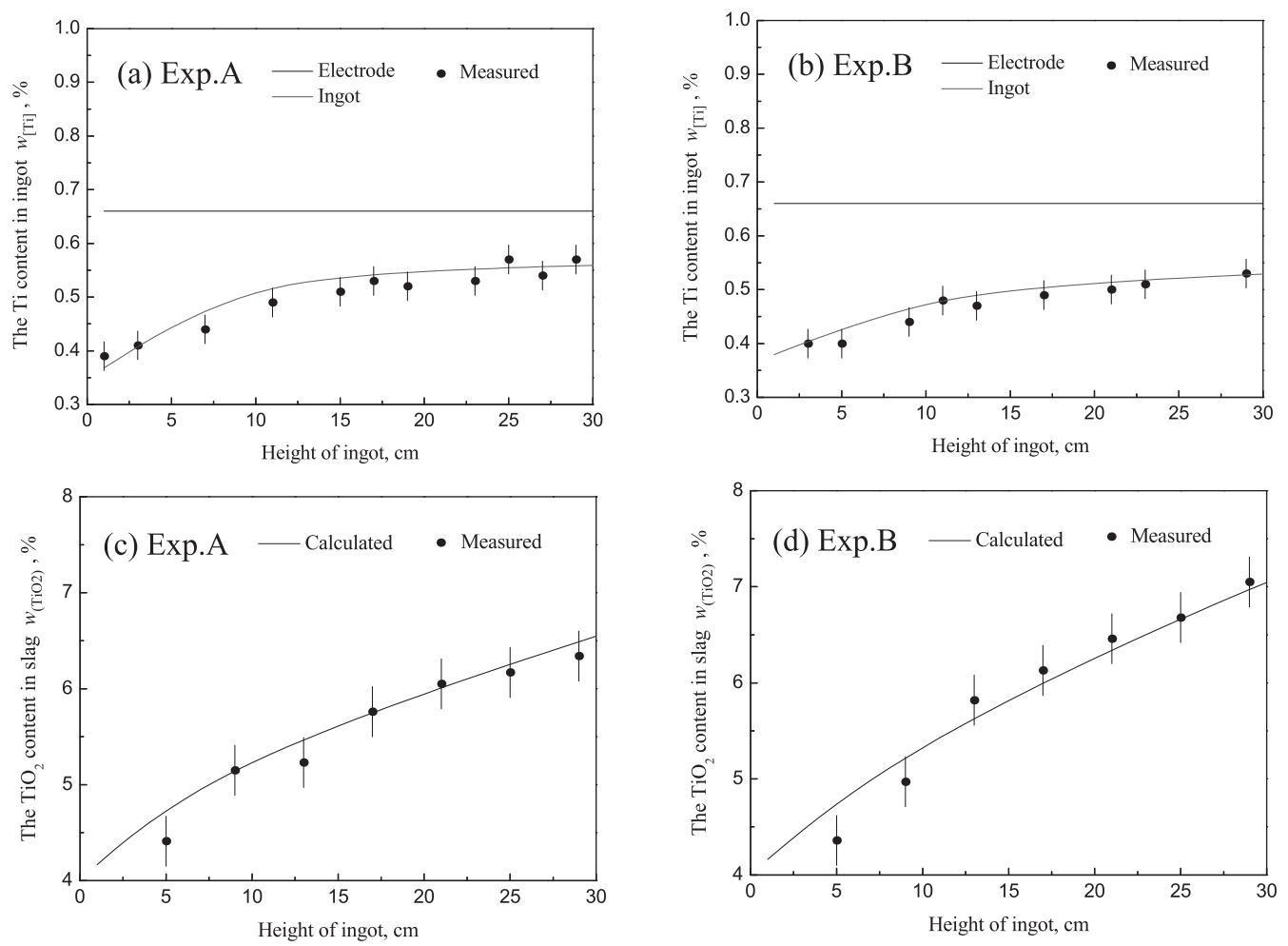

Fig. 9. Concentration of titanium in ingot, and of titania oxide in slag for experimental A and B.
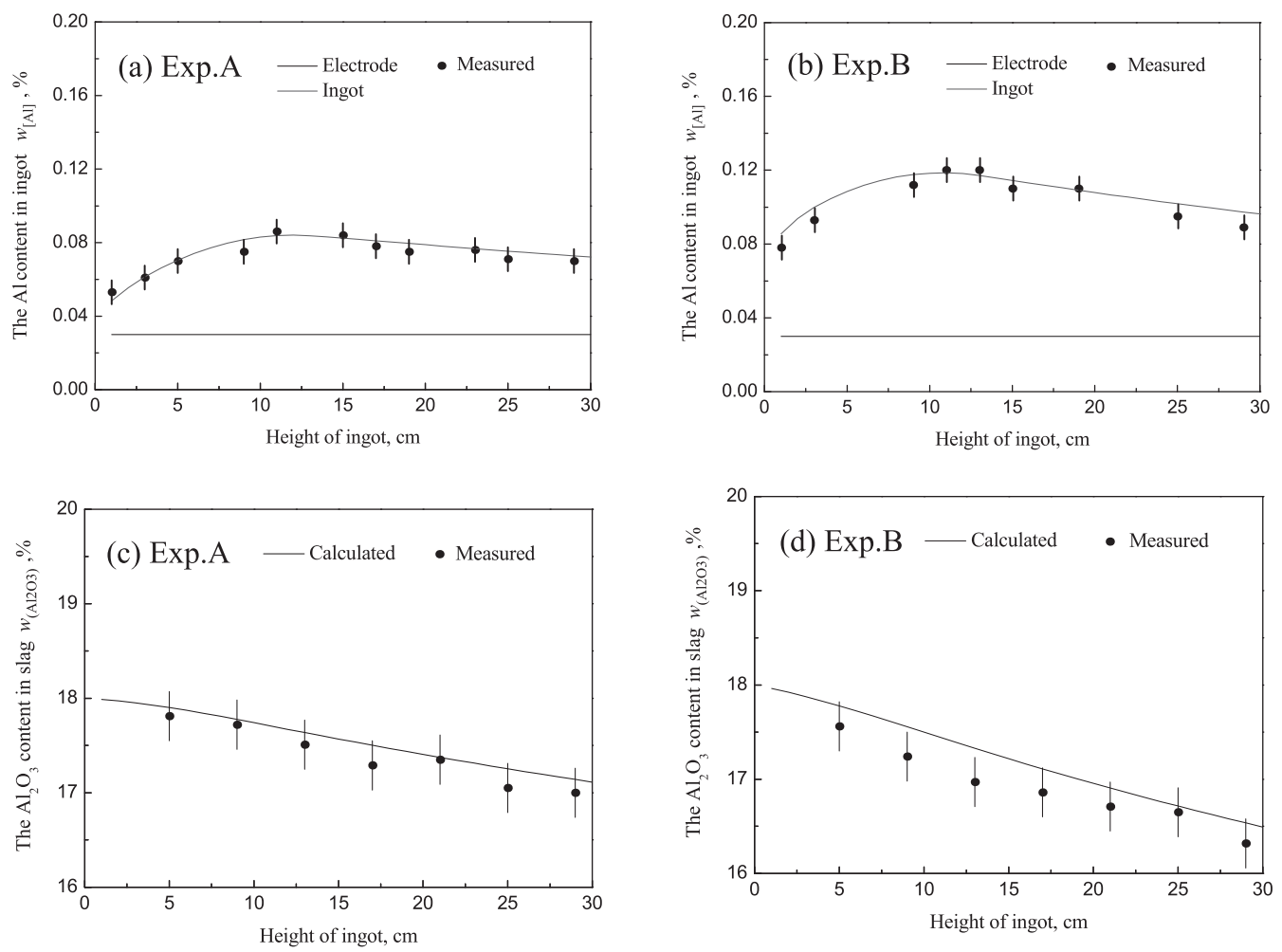

Fig. 10. Concentration of aluminum in ingot, and of alumina in slag for experimental A and B.

reaching the peak value at the $13 \mathrm{~cm}$ height of ingot, the aluminum content have the downward trend in the rest ingot. As the temperature increases in the first $13 \mathrm{~cm}$ height of ingot, the $\lg K(\mathrm{Ti}, \mathrm{Al})$ in Eq. (2) increases, which makes the aluminum content has the rising trend. While the temperature and $\lg K(\mathrm{Ti}, \mathrm{Al})$ in Eq. (2) are stable after the 13 $\mathrm{cm}$ height, the aluminum content decreases with the increase of $\mathrm{TiO}_{2}$ content in slag.

As shown in Fig. 11(d), even the slag S2 has higher silica content than slag S1 (Fig. 11(c)), the silicon content of ingot in experimental B (Fig. 11(b)) is less than that in the experimental A (Fig. 11(a)). According to the previous study, ${ }^{4)}$ the $\mathrm{CaO}$ has a great effect on the activities of $\mathrm{TiO}_{2}$, $\mathrm{SiO}_{2}$ and $\mathrm{Al}_{2} \mathrm{O}_{3}$. With the increase of $\mathrm{CaO}$ mass fraction in slag, the activity coefficient of $\mathrm{SiO}_{2}$ decreases significantly, whereas, slightly change happens for $\mathrm{Al}_{2} \mathrm{O}_{3}$ and $\mathrm{TiO}_{2}$. Thus, in order to prevent the losses of aluminum and titanium caused by reaction with the silica of the ESR slag, the slag 

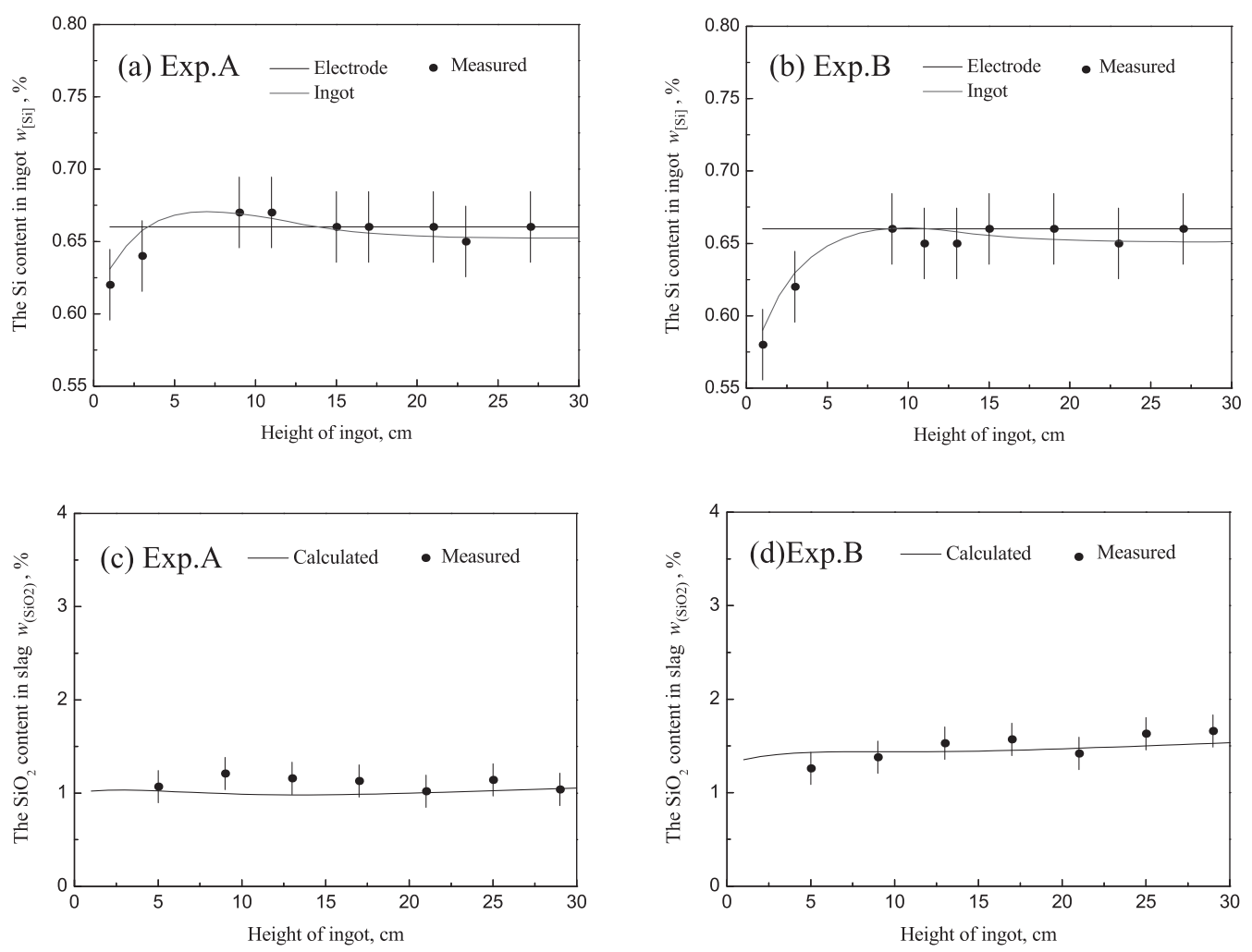

Fig. 11. Concentration of silicon in ingot, and of silica oxide in slag for experimental A and B.
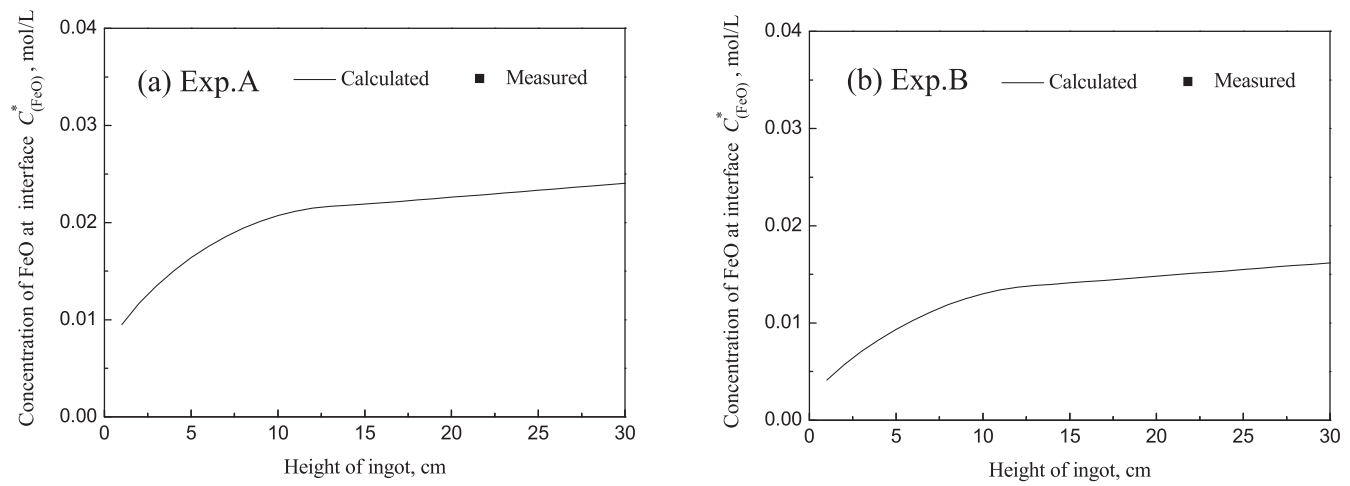

Fig. 12. Concentration of ferrous oxide at metal-slag interface for experimental A and B.

with low $\mathrm{CaO}$ (slag $\mathrm{S} 1$ ) should decrease the $\mathrm{SiO}_{2}$ content in slag. Especially for remelting steel and/or alloy with high titanium, low aluminum and low silicon content, not only should the slag have the low $\mathrm{CaO}$ content, but also decrease the silica content to a very low level.

It also can be concluded that at the beginning of the ESR process, the silicon content increases with the decrease of ferrous oxide shown in Fig. 7(a), and during the $4-12 \mathrm{~cm}$ height of ingot the silicon content in ingot being larger than that in electrode according to the Eq. (9) combined with the large increase of silica content in slag in the first $4 \mathrm{~cm}$ height of ingot. After $12 \mathrm{~cm}$ height of ingot, the silicon content decreases as the ferrous oxide at metal-slag interface increases, as shown in Fig. 12(a). At last, the Eq. (9) reaches the thermodynamic equilibrium in the rest process, both silicon and titanium content have the rising trend close to chemical composition in electrode according to the Eqs. (10)-(13).

$$
[\mathrm{Ti}]+\left(\mathrm{SiO}_{2}\right)=\left(\mathrm{TiO}_{2}\right)+[\mathrm{Si}]
$$

$$
\begin{gathered}
3[\mathrm{Si}]+2\left(\mathrm{Al}_{2} \mathrm{O}_{3}\right)=3\left(\mathrm{SiO}_{2}\right)+4[\mathrm{Al}] \\
{[\mathrm{Si}]+2(\mathrm{FeO})=\left(\mathrm{SiO}_{2}\right)+2[\mathrm{Fe}] \ldots . . .} \\
3[\mathrm{Ti}]+2\left(\mathrm{Al}_{2} \mathrm{O}_{3}\right)=3\left(\mathrm{TiO}_{2}\right)+4[\mathrm{Al}] \\
{[\mathrm{Ti}]+2(\mathrm{FeO})=\left(\mathrm{TiO}_{2}\right)+2[\mathrm{Fe}] \ldots . .}
\end{gathered}
$$

Based on the analysis above, the molar volume of $\mathrm{FeO}$ at the slag-metal interface during the molten metal pool $C_{(\mathrm{FeO})}^{*}$ can be obtained, as shown in Fig. 12. The $C_{(\mathrm{FeO})}^{*}$ of slag S1 being larger than that of slag S2 explained the higher aluminum content of ingot in experimental $\mathrm{B}$, as shown in Figs. 10(a) and 10(b).

Both in experimental A and B, the titanium in electrode plays a role of deoxidizer to decrease the ferrous oxide in slag. As shown in Fig. 4, the $\lg \left(\gamma_{\mathrm{TiO}_{2}} / \gamma_{\mathrm{FeO}}^{2}\right)$ increases with the increase of $\mathrm{TiO}_{2}$ content in slag, which would arouse the increase of $X_{(\mathrm{FeO})}^{3}$ according to the Eq. (6) in Part 1. ${ }^{11)}$ As shown in Fig. 12, the increase of, $\lg \left(\gamma_{\mathrm{TiO}_{2}} / \gamma_{\mathrm{FeO}}^{2}\right) X_{\mathrm{TiO}_{2}}$ 
and $T$ makes the $C_{(\mathrm{FeO})}^{*}$ increase in the first $13 \mathrm{~cm}$ height of ingot, and the increase of $\lg \left(\gamma_{\mathrm{TiO}_{2}} / \gamma_{\mathrm{FeO}}^{2}\right)$ and $X_{\mathrm{TiO}_{2}}$ makes the $C_{(\mathrm{FeO})}^{*}$ increase in the rest $17 \mathrm{~cm}$ height of ingot.

Then, the mass transfer resistance of the respective components on the metal side and slag side at the molten metal pool-slag in experimental A and B can be obtained using Eqs. (23)-(26) in Part 1,11) as shown in Table 4, Figs. 13(a) (Experimental A) and 13(b) (Experimental B). From this table, ${ }^{13)}$ it can be inferred that the chemical reaction Eq. (1) in Part 1, which is due to slag-metal reactions, is the ratedetermining steps of mass transfer on the metal side, the reaction in Eq. (2) in Part 1 is rate-determining for mass transfer on the slag side, and the reaction in Eq. (3) in Part 1 is rate-determining for mass transfer on both of the metal and slag sides.

Thus, the mass transfer of aluminum can be expressed by Eq. (14), and the $C_{[\mathrm{Al}]}^{*}$ at the metal/slag interface can be calculated by Eq. (16). ${ }^{13)}$ In each heat, as the $X_{\left(\mathrm{Al}_{2} \mathrm{O}_{3}\right)}$ changes very little, the change of aluminum in the rest $17 \mathrm{~cm}$ height of ingot is influenced by $X_{(\mathrm{FeO})}^{* 3}$. The aluminum content in ingot decreases with the increase of the show in Fig. 12.

$$
\begin{aligned}
& -d C_{[\mathrm{Al}]} / d t=j_{\mathrm{Al}} \frac{A}{V_{\mathrm{m}}}=\frac{A}{V_{\mathrm{m}}} k_{\mathrm{Al}}^{*}\left(C_{[\mathrm{Al}]}-C_{[\mathrm{Al}]}^{*}\right) \\
& 2[\mathrm{Al}]+3(\mathrm{FeO})=\left(\mathrm{Al}_{2} \mathrm{O}_{3}\right)+3[\mathrm{Fe}] \\
& \lg K_{\mathrm{Al}}=\lg \frac{a_{\mathrm{Al}_{2} \mathrm{O}_{3}}}{a_{\mathrm{Al}}^{* 2} \cdot a_{\mathrm{FeO}}^{* 3}}=\lg \frac{\gamma_{\mathrm{Al}_{2} \mathrm{O}_{3}} X_{\mathrm{Al}_{2} \mathrm{O}_{3}}}{f_{\mathrm{Al}}^{2}\left[\% \mathrm{Al}^{*}\right]^{2} \cdot \gamma_{\mathrm{FeO}}^{3} X_{\mathrm{FeO}}^{* 3}} \\
& =\frac{22604}{T}-6.3265
\end{aligned}
$$

It also can be seen from Fig. 4 that the $\lg \left(\gamma_{\mathrm{Al}_{2} \mathrm{O}_{3}}^{2} / \gamma_{\mathrm{TiO}_{2}}^{3}\right)$ decreases with the increase of $\mathrm{TiO}_{2}$ content, which would intensify the decrease of the aluminum in ingot according the Eq. (2) in the rest $17 \mathrm{~cm}$ height of ingot. Thus, preventing titanium from oxidation to titania is essential to control the aluminum content, and aluminum is suitable to be deoxidizer compared with titanium element.

Table 4. Mass transfer resistances of each component.

\begin{tabular}{ccccc}
\hline $\begin{array}{c}\text { Mass } \\
\text { transfer } \\
\text { Resistance }\end{array}$ & $\begin{array}{c}\text { Each element } \\
\text { in molten } \\
\text { steel }\end{array}$ & $\begin{array}{c}\mathrm{SiO}_{2} \\
\text { In molten slag }\end{array}$ & $\begin{array}{c}\mathrm{AlO}_{1.5} \\
\text { in molten slag }\end{array}$ & $\begin{array}{c}\mathrm{TiO}_{2} \\
\text { in molten slag }\end{array}$ \\
\hline Expression & $\frac{1}{k_{\mathrm{m}}}$ & $\frac{1}{k_{\mathrm{Si}, s} \Omega_{\mathrm{Si}} C_{(\mathrm{FeO})}^{* 2}}$ & $\frac{1}{k_{\mathrm{Al}, s} \Omega_{\mathrm{Al}} C_{(\mathrm{FeO})}^{* 1.5}}$ & $\frac{1}{k_{\mathrm{Ti}, s} \Omega_{\mathrm{Ti}} C_{(\mathrm{FeO})}^{* 2}}$ \\
\hline
\end{tabular}

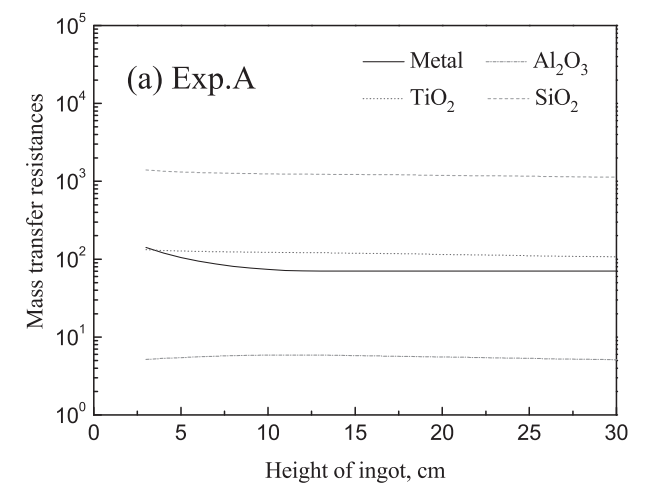

The agreement of the simulation created in the Part $1^{11)}$ with the measured values proves that the values cited from the previous studies, including the reaction time $t_{\mathrm{d}}$, droplet velocity and slag velocity at the droplet, are quite valid.

\subsubsection{Experimental $\mathrm{C}$}

It is the final goal to produce an ESR ingot with a homo-
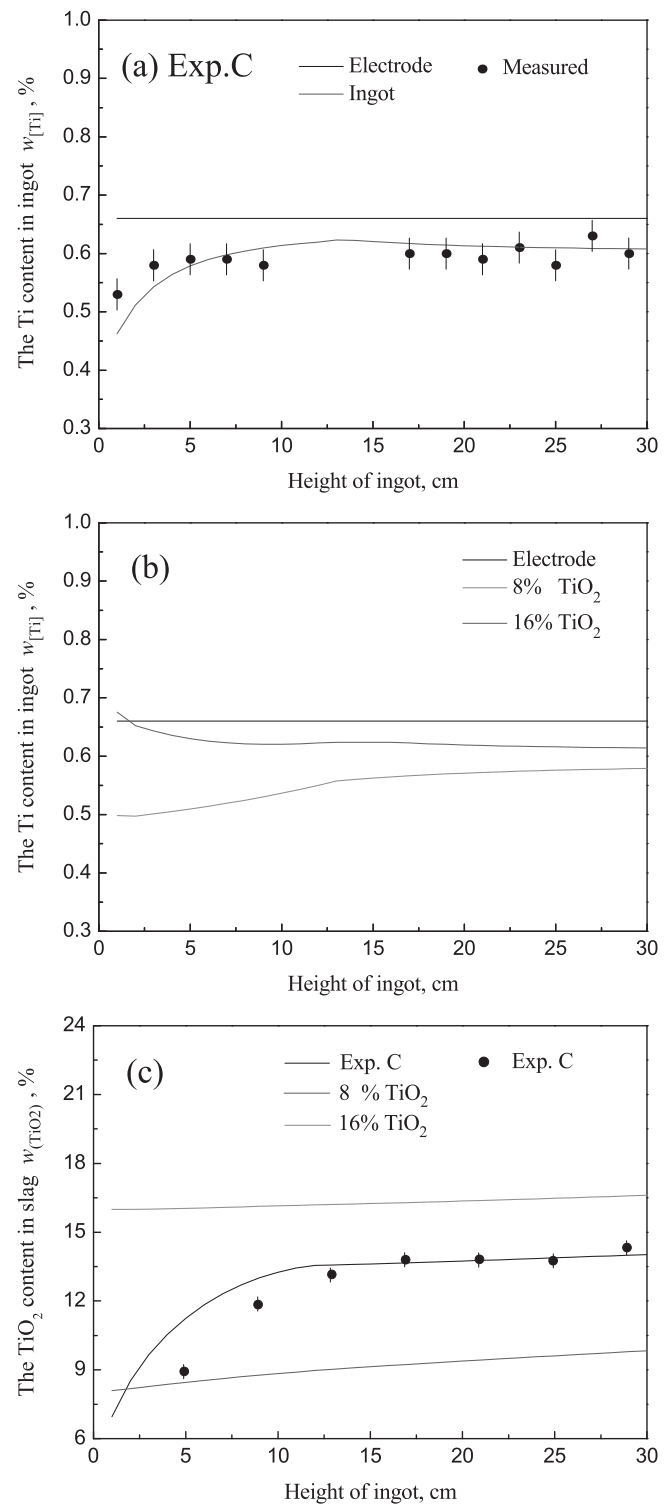

Fig. 14. Concentration of titanium in ingot, and of titania oxide in slag for experimental C, SS1 and SS2.

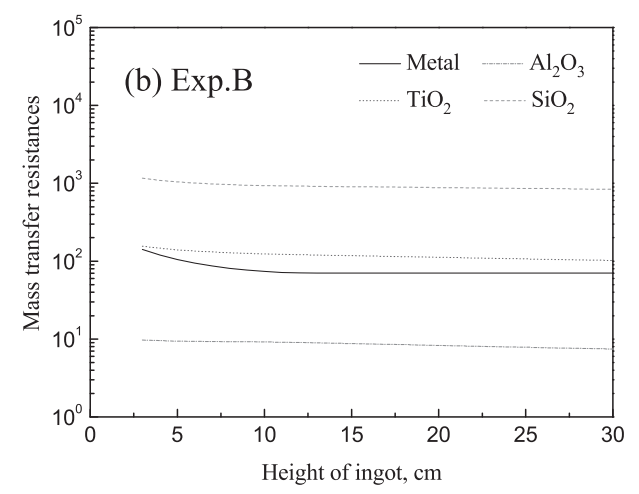

Fig. 13. Mass transfer resistances of each component in metal and slag. 
geneous distribution especially in $\mathrm{Al}$ and Ti contents. Based on the mass transfer model established in Part $1,{ }^{11)}$ the experimental results of experimental $\mathrm{C}$ were investigated, as shown in Figs. 14(a) and 14(c), 15(a) and 15(c), 16(a) and 16(c), respectively. In order to investigate the effect of $\mathrm{TiO}_{2}$ content in the initial slag on the concentration of each alloying element, the slag SS1 and SS2 (the $\mathrm{TiO}_{2}$ content in each slag are calculated by thermodynamic equilibrium at
$1750 \mathrm{~K}$ and $1950 \mathrm{~K}$, respectively) listed in Table 5 were investigated by mass transfer model under the condition of no $\mathrm{TiO}_{2}$ added into molten slag during the remelting process, as shown in Figs. 14(b) and 14(c), 15(b) and 15(d), 16(b) and 16(d), respectively.

As shown in Figs. 14(a) and 15(a), the macrosegregation of aluminum and titanium content along the axial direction of ingot in Experimental $\mathrm{C}$ are largely improved compared
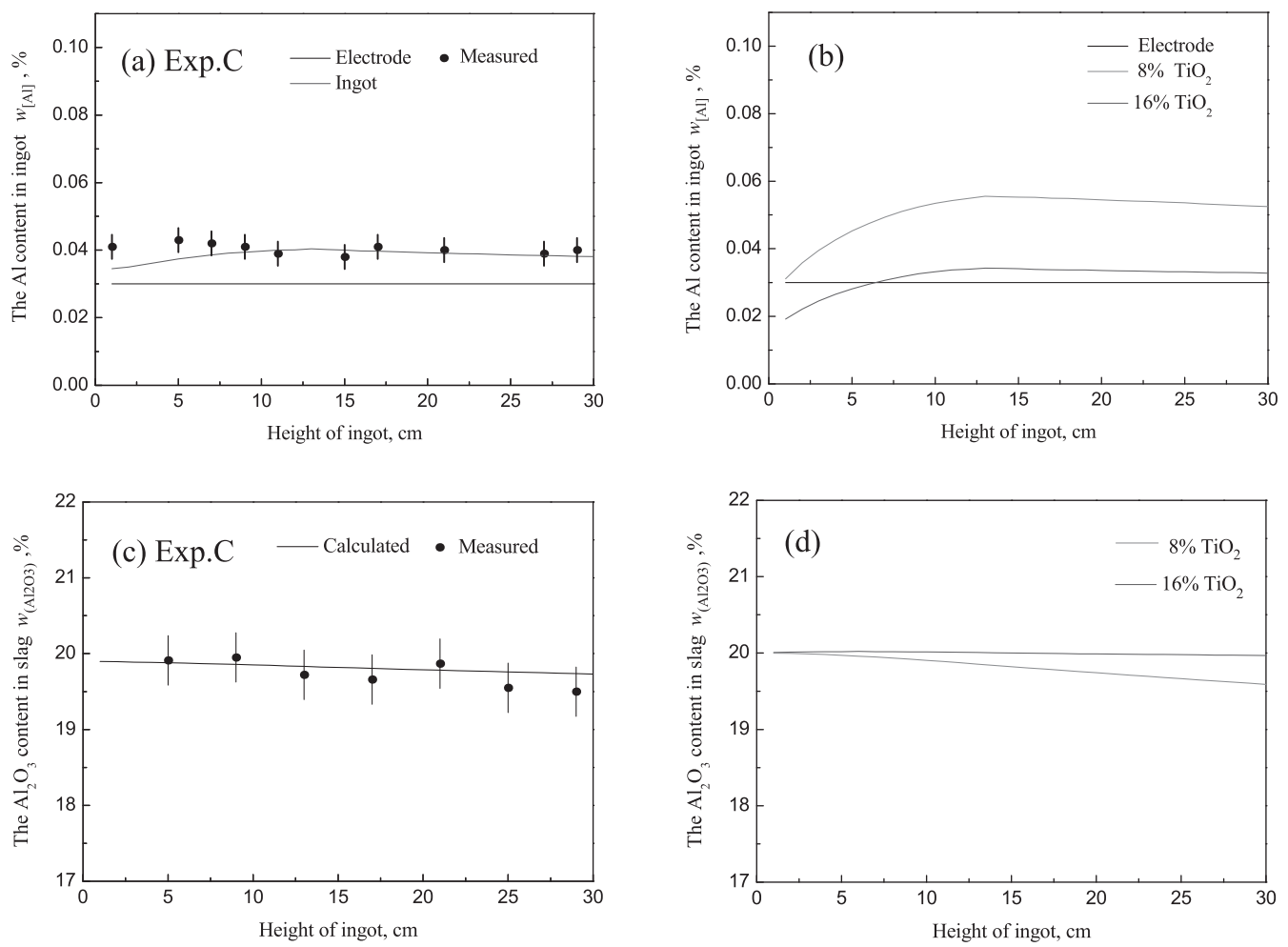

Fig. 15. Concentration of aluminum in ingot, and of alumina oxide in slag for experimental C, SS1 and SS2.
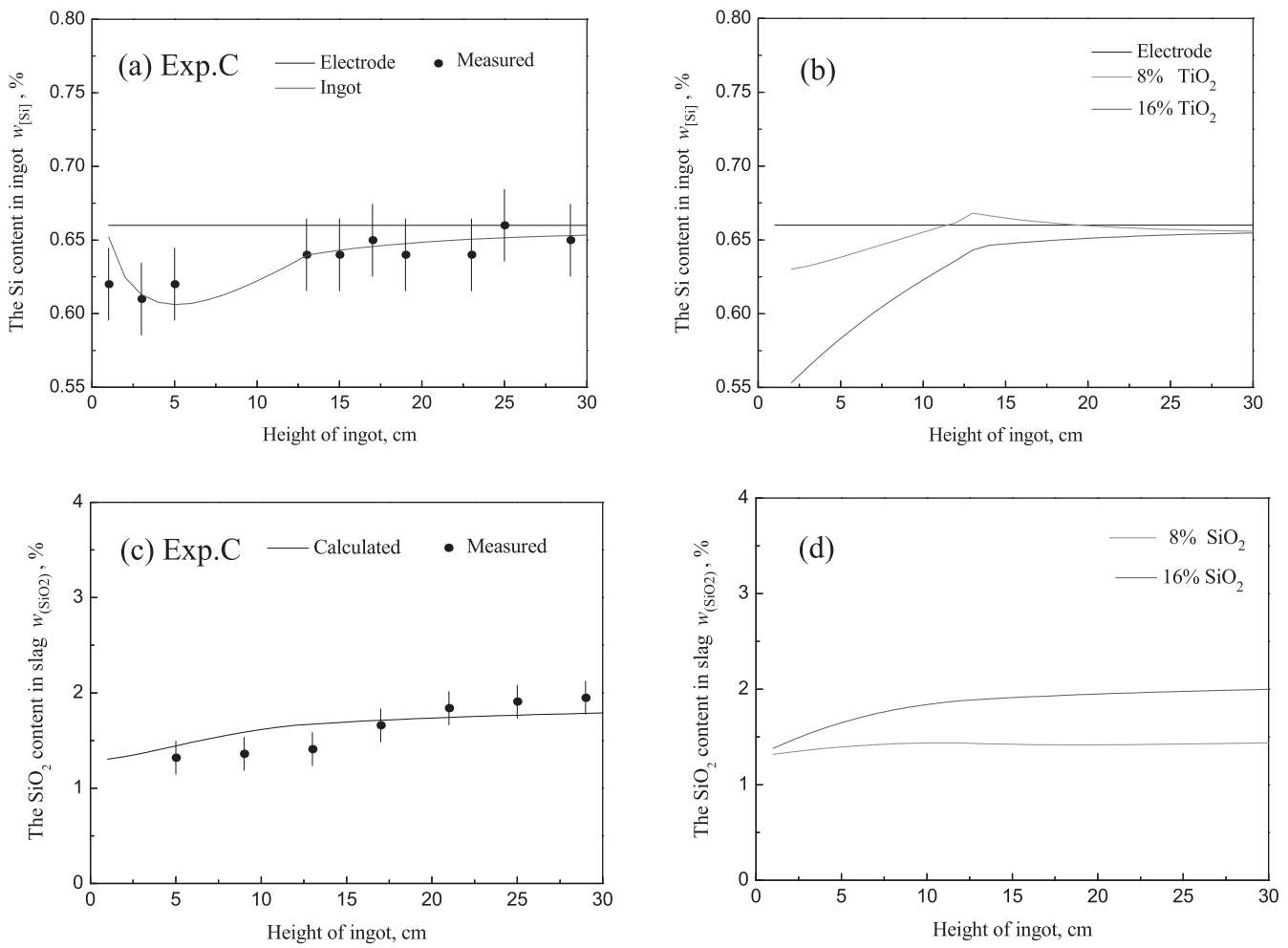

Fig. 16. Concentration of silicon in ingot, and of silica oxide in slag for experimental C, SS1 and SS2. 
Table 5. Chemical composition of ESR slag (wt\%).

\begin{tabular}{cccccc}
\hline Slag & $\mathrm{CaF}_{2}$ & $\mathrm{CaO}$ & $\mathrm{Al}_{2} \mathrm{O}_{3}$ & $\mathrm{TiO}_{2}$ & $\mathrm{MgO}$ \\
\hline $\mathrm{SS} 1$ & 57 & 5 & 20 & 8 & 10 \\
$\mathrm{SS} 2$ & 49 & 5 & 20 & 16 & 10 \\
\hline
\end{tabular}

with the ingots in Experimental A and B. Aluminum content in ingot ranges from $0.036 \mathrm{wt} \%$ to $0.048 \mathrm{wt} \%$, and titanium content in ingot ranges from $0.53 \mathrm{wt} \%$ to $0.63 \mathrm{wt} \%$, respectively. And the change of $\mathrm{TiO}_{2}$ content in slag with height caused by extra addition of $\mathrm{TiO}_{2}$ during the remelting process is shown in Fig. 14(c).

At the beginning of the ESR process, the titanium and silicon was reduced by Eqs. (11) and (13), as shown in Figs. 14(a) and 16(a). As the temperature and $\mathrm{TiO}_{2}$ content in slag increase, the silicon content in ingot decreases in the first 5 minutes, and after reaching the valley value, silicon content has the rising trend to chemical composition in electrode.

As shown in Figs. 15(a) and 15(b), the aluminum content in experimental $\mathrm{C}$ is homogeneous along the height of ingot compared with that in traditional experimental SS1 and SS2, which illustrates the superiority of the remelting process by adding extra $\mathrm{TiO}_{2}$ into molten slag in the first temperaturerising period.

According to the previous study, ${ }^{3)}$ several kinds of slag containing different $\mathrm{CaO}$ content combined with steel samples of $1 \mathrm{Cr} 21 \mathrm{Ni5Ti}$ were employed to illustrate the effect of $\mathrm{CaO}$ on $\lg \left(\gamma_{\mathrm{Al}_{2} \mathrm{O}_{3}}^{2} / \gamma_{\mathrm{TiO}_{2}}^{3}\right)$ based on thermodynamic analysis in an electrical resistance furnace. And present study illustrates the effect of $\mathrm{CaO}$ in slag on the change of aluminum, titanium and silicon content based on kinetic analysis during the ESR process. After determining the $\mathrm{CaO}$ content, the present study also investigate the effect of $\mathrm{TiO}_{2}$ content in slag on the concentration of each alloying element further. This study aims to provide appropriate slag and remelting process which can be applied to effectively control alloying elements content during the ESR of steel/alloy with high titanium and low aluminum content. In addition, with the application of rare earth elements ( $\mathrm{La}, \mathrm{Ce}$ ) in steel, the rare earth elements control technology during the ESR of steel/ alloy with $\mathrm{La}, \mathrm{Ce}$, Ti, Si, Al and other alloying elements would be investigated based on this study.

\section{Conclusions}

In order to clarify the effect of slag containing different $\mathrm{CaO}$ and $\mathrm{TiO}_{2}$ content on titanium and aluminum content in ESR ingots, kinetics of slag/metal reaction were investigated experimentally using a $50 \mathrm{~kg}$ ESR furnace. The results were presented as follows.

(1) The lower $\mathrm{CaO}$ in slag is, the smaller numerical value of $\lg \left([\mathrm{Al}]^{4} /[\mathrm{Ti}]^{3}\right)$ in ingot is. The $\lg \left([\mathrm{Al}]^{4} /[\mathrm{Ti}]^{3}\right)$ would increase with the increase of slag temperature at the beginning of the ESR process, while decrease with the increase of $\mathrm{TiO}_{2}$ content after the temperature reaches stable. Slag with low $\mathrm{CaO}$ content is suitable for $1 \mathrm{Cr} 21 \mathrm{Ni} 5 \mathrm{Ti}$ stainless steel electroslag remelting.

(2) The value of $\lg \left(\gamma_{\mathrm{Al}_{2} \mathrm{O}_{3}}^{2} / \gamma_{\mathrm{TiO}_{2}}^{3}\right)$ decreases with the increase of $\mathrm{TiO}_{2}$ content, which made the slope of slag designing diagram at a fixed temperature $\left(\lg \left(X_{\mathrm{TiO}_{2}}^{3} / X_{\mathrm{Al}_{2} \mathrm{O}_{3}}^{2}\right) / \lg \left([\mathrm{Ti}]^{3} /[\mathrm{Al}]^{4}\right)\right)$ less than one. Then, the slag designing diagram was acquired based on the thermodynamic equilibrium.

(3) The mass transfer model based on penetration and film theories shows good agreement with the experiments. The rate determining step of the reaction was the mass transfer of alumina through the molten steel, silica through the slag and titania on both of the metal and slag sides.

(4) The $\lg \left(\gamma_{\mathrm{Al}_{2} \mathrm{O}_{3}}^{2} / \gamma_{\mathrm{TiO}_{2}}^{3}\right)$ decreases with the increase of $\mathrm{TiO}_{2}$ content, which would intensify the decrease of the aluminum in ingot. In order to keep the uniformity of aluminum content along the height of ingot, aluminum is suitable to be deoxidizer compared with titanium element.

(5) The results of experimental $\mathrm{C}$ show that the appropriate slag combined with extra $\mathrm{TiO}_{2}$ added into molten slag in the first temperature-rising period is applied to effectively control alloying elements content during the ESR process.

\section{Acknowledgements}

This project is supported by Joint Research Fund of National Nature Science Foundation of China and Baosteel Group Corporation with the grant No. U1560203, and it is also supported by the National Nature Science Foundation of China with the grant No. 51274266.

\section{REFERENCES}

1) V. Weber, A. Jardy, B. Dussoubs, D. Ablitzer, S. Ryberon, V. Schmitt, S. Hans and H. Poisson: Metall. Mater. Trans. B, 40 (2009), 271.

2) S. K. Matity, N. B. Ballal, G. Goldhahn and R. Kwaalla: ISIJ Int., 49 (2009), 902.

3) D. Hou, Z. H. Jiang, Y. W. Dong, Y. L. Cao, H. B. Cao and W. Gong: Ironmaking Steelmaking, 43 (2016), 517.

4) Z. H. Jiang, D. Hou, Y. W. Dong, Y. L. Cao, H. B. Cao and W. Gong: Metall. Mater. Trans. B, 47 (2016), 1465.

5) Z. B. Li: Electroslag Metallurgy Theory and Practice, Metallurgical Industry Press, Beijing, (2010), 141.

6) Z. H. Jiang: The Physical Chemistry and Transmission during Electroslag Remelting, Northeastern University Press, Shenyang, (2000), 154.

7) V. P. Kubikov, M. M. Klyuev and A. A. Sisev: Steel USSR, 17 (1987), 503

8) G. Pateisky: J. Vac. Sci. Technol., 9 (1972), 1318.

9) K. Blazenko and W. Holzgruber: Berg. Hüettenmäenn. Monatsh., 123 (1978), 17.

10) K. Schwerdtfeger, W. Wepner and G. Pateisky: Ironmaking Steelmaking, 5 (1978), 135.

11) D. Hou, Z. H. Jiang, Y. W. Dong, W. Gong, Y. L. Cao and H. B. Cao: ISIJ Int., 57 (2017), 1399.

12) C. B. Shi, X. C. Chen, H. J. Guo, Z. J. Zhu and H. Ren: Steel Res. Int., 83 (2012), 472.

13) G. Okuyama, K. Yamaguchi, S. Takeuchi and K. Sorimachi: ISIJ Int., 40 (2000), 121. 